УДК [904 : 069.01] (477.73)

DOI: https://doi.org/10.33782/eminak2019.1(25).308

\title{
ПРО СТАН І ПЕРСПЕКТИВИ МУЗЕЙНО-ФОНДОВОЇ РОБОТИ В НІАЗ «ОЛЬВІЯ» НАН УКРАЇНИ
}

\author{
Тетяна Шевченко \\ Національний історико-археологічний заповідник «Ольвія» НАН України \\ (с. Парутине, Миколаївська область, Україна) \\ e-mail: tanua.shevchenko@ukr.net \\ ORCID: https://orcid.org/0000-0002-4237-8074
}

Стаття присвячена короткому огляду історії формування археологічного зібрання, що зберігається у Наукових фондах і музеї НІАЗ «Ольвія» НАН України. Розглянуті основні причини створення фондосховища та музею на місці розкопок, змальовано їх сучасний стан, окреслені нагальні проблеми збереження й опрацювання численних археологічних колекцій з розкопок некрополю, Ольвії та поселень ії хори, які у ньому зберігаються.

Ключові слова: НІАЗ «Ольвія», фонди, музей, антична археологія, національне надбання

Історія Національного історико-археологічного заповідника «Ольвія» НАН України тісно пов'язана з історією Інституту археології НАН України. Саме ця наукова установа впродовж вже майже століття веде наукові й охоронні археологічні дослідження Ольвії у межах городища, передмістя, приміського некрополя та значної за розмірами території сільськогосподарської округи, а останніми десятиріччями - ще й на острові Березань (античний Борисфен).

Відомо, що наприкінці XVIII - початку XIX ст. розпочалися перші спроби вивчення Ольвії. Саме перші дослідники залишили детальні описи городища, його стану, топографічні плани, опублікували деякі археологічні знахідки, переважно лапідарні написи ${ }^{1}$. Перші невеликі розкопки на городищі та некрополі Ольвії провів ще на самому початку XIX ст. І.П. Бларамберг. Відомо також про існування у нього приватної колекції, що налічувала не одну сотню предметів, до складу якої входили переважно монети, знайдені в Ольвії. Саме її він пізніше подарував різним установам Одеси, у тому числі створеному в 1825 р. Одеському археологічному музею2.

Ще у 1803 р. в Миколаєві було організовано Кабінет старожитностей Чорноморського депо карт - перше державне зібрання старожитностей у Російській імперії, де впродовж першої третини XIX ст. зберігалася значна кількість ольвійських знахідок. Проте подальша доля цього зібрання ще й дотепер залишається невідомою3. Крім того, знахідки зі спорадичних розкопок Ольвії, які проводилися фахівцямиархеологами з різних наукових установ Російської імперії у другій половині XIX ст. та численні приватні колекції, що формувалися переважно з матеріалів (серед них -

\footnotetext{
1 Тункина И.В. Русская наука о классических древностях Юга России (XVIII - середина XIX в.). Санкт-Петербург: Наука, 2002. С. 54, рис. 6.

2 Тункина И.В. К истории изучения Ольвии в конце XVIII - начале XIX в. // Древнее Причерноморье. Чтения памяти профессора П.О. Карышковского. Тезисы докладов конференции. Одесса, 1989. С. 5254; Тункина И.В. К истории изучения Ольвии в первой трети ХХ в. // Археологія. 2001. № 4. С. 35-50; Тункина И.В. Русская наука о классических древностях Юга России... С. 110-111.

3 Тункина И.В. Русская наука о классических древностях Юга России... С. 190.
} 
найвідоміша колекція німецького негоціанта А. Фогеля), здобутих хижацькими роботами на некрополі4 ${ }^{4}$ виявилися розпорошеними по значній кількості музейних установ Росії, України, а також країн Західної Європи та Північної Америки.

Ситуація докорінно змінилася з початком розкопок Археологічною комісією під керівництвом Б.В.Фармаковського. Однак, навіть за погодженням Археологічної комісії, половину всіх знахідок потрібно було передавати володарю землі, на якій знаходилася Ольвія, - саме такі умови спочатку висунули Мусіни-Пушкіни, давши дозвіл на початок археологічних досліджень 5 .

Матеріали з дореволюційних розкопок Ольвії відповідно до задокументованих і, найголовніше, надрукованих у щорічних звітах актів передавалися на постійне збереження до Державного Ермітажу згідно до загальних правил Археологічної комісії. Саме вона розподіляла археологічні знахідки по діючим на той час музейним установам. Крім Ермітажу, куди поступала абсолютна більшість ольвійських знахідок, їх певна кількість направлялася до археологічних музейних зібрань Одеси, Херсона ${ }^{6}$ та Миколаєва. Проте, невелика кількість знахідок, передусім, великогабаритних виробів з каменю, залишалася на місці, в Ольвії. Вони і сьогодні з незначними втратами знаходяться на зберіганні у лапідарії НІАЗ «Ольвія» НАН України. Саме ці експонати, ще за відсутності стаціонарного музею в Ольвії, поклали початок формуванню зібрання пам'яток безпосередньо на місці розкопок.

Переломні події в історії країни 1917-1920 рр. залишили нездійсненою мрією Б.В. Фармаковського питання про організацію свого музею в Ольвії7.

Пізніше, у 1920-1921 рр. поновлені археологічні дослідження ольвійського городища та некрополя перейшли під керівництво С.А. Семенова-Зусера8. Нарешті, Постановою РНК УСРР «Про охорону залишків старогрецького міста Ольвія» (13.09.1921 р.) археологічну пам'ятку Ольвія та її некрополь було взято під охорону держави, їх оголошено національною власністю, а всі знахідки передавалися до Миколаївського обласного історико-археологічного музею9. У період 1921-1924 pр. Ольвія охоронялася, для відвідувачів проводилися екскурсії городищем, велися роз'яснювальні роботи з місцевим населенням щодо необхідності збереження й охорони старожитностей. Усіма заходами керував завідуючий Миколаївським історико-археологічним музеєм Ф.Т. Камінський.

У 1924 р. було прийнято рішення про відновлення наукових археологічних досліджень Ольвії. Керівництво розкопками з 1924 по 1926 рр. здійснював Б.В.Фармаковський в якості професора Ленінградського університету, з 1927 до 1935 рр. - Тимчасова наукова Рада Укрнауки. По 1930 р. включно Тимчасова Рада працювала за перспективним планом дослідження міста та некрополя, окресленим

\footnotetext{
${ }^{4}$ Крапівіна В.В. Ольвія: проблеми охорони та археологічні дослідження // Археологія. 2001. № 4. C. 6-7.

5 Карасев А.Н. Б.В. Фармаковский и Ольвия // Художественная культура и археология античного мира. Ленинград: Наука, 1976. С. 13.

6 Костенко А.В. Археологічні фонди краєзнавчого музею: формування, зберігання, використання (на прикладі Херсонського обласного краєзнавчого музею). Автореф. дис... канд. іст. наук. Київ, 2015. С. 6.

7 Фармаковская Т.И. Борис Владимирович Фармаковский. Киев: Наук. думка, 1988. С. 174; Крапівіна В.В. Ольвія: проблеми охорони та археологічні дослідження // Археологія. 2001. № 4. С. 8. 8 Папанова В.А. Урочище Сто могил (некрополь Ольвии Понтийской). Киев: Знання України, 2006. C. $48-49$.

9 Крапівіна В.В. Вказ. праця. С. 9.
} 
Б.В. Фармаковським у 1924 р. перед початком поновлених досліджень ${ }^{10}$. Роботами до 1917 р. Б.В. Фармаковському вдалося окреслити основні топографічні вузли городища, дослідити залишки споруд переважно елліністичного часу та перших століть н.е., відкрити низку поховань на міському некрополі, який найбільше потерпав від грабіжницьких покопів. На території міста - це два великих елліністичних будинки у Нижньому місті, квартал будинків елліністичного часу в центрі Верхнього міста, прясла оборонного муру цитаделі перших століть н.е., трикамерна башта над Заячою балкою перших століть н.е. із залишками оборонного муру елліністичного часу, два монументальних склепи, Зевсів курган і склеп Єврисивія й Арети перших століть н.е. ${ }^{11}$ Розпочинаючи новий цикл робіт на городищі, Б.В. Фармаковський означив ті райони міста, роботи на яких проводилися також після його смерті у 1928 р. та були закінчені у другій половині 1940-х рр.

Новою постановою РНК УСРР від 31.05.1924 р. «Про охорону стародавньої грецької колонії Ольвії» територія пам'ятки оголошувалася «національним добром УСРР»12. У 1926 р. Постановою РНК УРСР (03.03.1926 р., № 32-38, арт. 259) було створено Державний заповідник «Ольвія» ${ }^{13}$. Ця видатна подія для пам'яткоохоронної діяльності загалом і Ольвії зокрема, дала вагомий імпульс для організації постійно діючої археологічної експедиції на території Ольвії. Створення державного заповідника зіткнулося 3 необхідністю створення належної організаційної та наукової структури. Проте, відсутність необхідних приміщень та умов для зберігання археологічних знахідок призводила до того, що матеріали з розкопок Ольвії поступали на зберігання до Миколаївського обласного історико-археологічного музею, починаючи від 1920 р. до 1930 р. Сьогодні вони становлять основу ольвійської колекції цього музейного зібрання 14.

У 1936 р. Ольвійську експедицію очолив учень Б.В. Фармаковського, майбутній член-кореспондент АН УРСР Л.М. Славін, який керував розкопками городища та некрополя по 1940 р., а потім незмінно з 1946 по 1971 р. Постановою РНК УРСР (№ 1043 від 29.07.1938 р.) заповідник «Ольвія» було передано до Академії наук УРСР15. Відтоді у науково-організаційному плані ним став опікуватися Інститут археології, директором якого і став Л.М. Славін. Матеріали з розкопок 1935 по 1940 рр. частково передавалися на зберігання до Центрального історичного музею в Києві (тепер - Національний музей історії України). Серед них особливо слід відзначити ті знахідки, що походять з раннього некрополя, відкритого у північній частині городища і становлять значний науковий та експозиційний інтерес й активно залучаються у виставковій діяльності.

Формування власного фондосховища у заповіднику «Ольвія» починається 3 1935 р. Від самого початку фондосховище формується не за принципом зберігання

\footnotetext{
10 Славин Л.М. Основные этапы изучения Ольвии // Записки Одесского археологического общества. 1960. Т. 1. С. 47; Папанова В.А. Указ.раб. С. 54-55.

${ }^{11}$ Карасев А.Н. Указ. раб. С. 14.

12 Інститут археології Національної академії наук України. 1918-2014 / Толочко П.П. (ред.). Київ, 2015. C. 147.

13 Крапівіна В.В. Вказ. праця. С. 9.

14 Буйских А.В., Чепкасова М.И. Коллекция восточногреческой и коринфской керамики из Ольвии в собрании Николаевского обласного краеведческого музея (общая характеристика) // Історія. Етнографія. Культура. Нові дослідження. VIII Миколаївська краєзнавча конференція. Миколаїв, 2010. C. 81-82.

15 Інститут археології Національної академії наук України. 1918-2014... С. 147.
} 
експозиційних або рідкісних речей, а за принципом формування комплексного зібрання археологічних колекцій з масовим археологічним матеріалом. Саме цей принцип застосовувався при створенні Наукового фондосховища Інституту археології НАНУ, яке на сьогодні $\epsilon$ найбільшим зібранням археологічних колекцій усіх історичних періодів України ${ }^{16}$. Скоріше за все, разом з фондами в Ольвії було створено і музей, незважаючи на те, що точної дати створення музею нам поки не вдалося встановити. Проте відомо, що заповідник зазнав чималих втрат під час фашистської окупації, а з музею було вивезено експонати ${ }^{17}$.

Це $\epsilon$ прямим свідченням, що музей в Ольвії було створено до 1941 р. В архіві НІАЗ з документації довоєнного часу збереглися лише книги опису археологічних знахідок. На жаль, не набагато краща картина у плані збереження облікової документації щодо археологічного матеріалу і за 1960-70-і рр. Можна лише констатувати, що, попри зберігання у фондах заповідника значної частини археологічних колекцій, чітких вимог до передачі їх за відповідними актами не було дотримано, а статус фондів, як місця збереження саме археологічних колекцій, що складалися з масових матеріалів - не визначено.

Починаючи з 1981 р., практично всі археологічні матеріали, знайдені під час розкопок Ольвійської археологічної експедиції ІАНАНУ, надходять на постійне збереження до НІАЗ «Ольвія» згідно актів передачі та з відповідними колекційними описами. Оскільки, на жаль, попередні колекції не супроводжувалися такими документами, тому створення сучасних колекційних описів на них, систематизація численного археологічного матеріалу по роках і по типах матеріалів, передовсім - кераміки, $€$ важливою ланкою роботи співробітників Наукових фондів НІАЗ. Ця системна робота продовжується зараз вже у рамках планових науково-дослідних завдань Відділу археологї̈ Нижнього Побужжя, створеного у НІАЗ «Ольвія» 2016 р.

Станом на сьогодні археологічна колекція заповідника містить 131474 одиниці зберігання, з них 465 одиниць знаходяться на постійній виставці музею кераміки, близько 1000 одиниць експонується у лапідарії, ще 68 одиниць зберігання надано на постійно діючу виставку до Миколаївського обласного краєзнавчого музею «Старофлотські казарми», з яким НІАЗ підтримує давні та тісні стосунки. Завдяки роботам Ольвійської археологічної експедиції ІА НАНУ Наукові фонди НІАЗ «Ольвія» щорічно поповнюються новими знахідками, як масовими, так і презентабельними чи експозиційними.

Через те, що у Наукових фондах НІАЗ«Ольвія», як і в музеї кераміки, через брак необхідних умов зберігання та загалом - приміщення, яке відповідало б сучасним умовам зберігання археологічного матеріалу, ще й до тепер неможливо забезпечити необхідний температурно-вологістний режим, частина знахідок - такі як нумізматичний матеріал, а також деякі категорії металевих виробів, вилучаються та передаються за відповідними Актами на постійне зберігання до Наукових фондів Інституту археології НАН України. Вкрай лімітована експозиційна площа музею кераміки HIA3 «Ольвія» не дозволяє розгорнути таку експозицію, що дала б змогу повноцінно охарактеризувати всі сторони життя античної Ольвії впродовж тисячолітнього періоду їі існування. Тому діюча експозиція музею кераміки у НІАЗ відображає лише певні тематичні напрямки, такі як найраніші імпорти до Ольвії, основні типи довіз-

\footnotetext{
16 Бурдо Н.Б., Сон Н.О. Вступ // Каталог «Колекції Наукових фондів ІА НАНУ. Київ: Академперіодика, 2007. С. 5.

17 Славін Л.М. Стан Ольвійського заповідника Академії наук УРСР // Археологія. 1947. Вип. 1. С. 193.
} 
ного посуду доримського та римського часів, знахідки з некрополя, господарчий куточок з основними типами господарчого посуду, гончарного та ліпленого, а також основні види місцевого керамічного та взагалі ремісничого виробництва.

Для демонстрації хоча б невеликої частини нових надходжень у круглій залі музею періодично влаштовуються тимчасові виставки. Зокрема, для такої форми експонування було залучено відреставровані знахідки останніх років, що походять 3 некрополя Ольвії та Борисфена. Крім цілих знахідок було вирішено доречним залучати до тимчасових експонувань також кращі взірці розписного довізного посуду, представлених фрагментами. Це передовсім стосується аттичного чорно- та червонофігурного посуду, в тому числі з графіті. Вони яскраво доповнюють не лише експозиційний фонд, а й слугують наочною презентацією численних питань торгівлі, релігії та щоденного побуту ольвіополітів, про які йде мова під час туристичного супроводу. Крім масового матеріалу з розкопок у Наукових фондах зберігається окремо виділений допоміжний фонд музею. Він складається з відреставрованих і цілих форм попередніх і сучасних років розкопок Ольвії та її хори ${ }^{18}$.

За останні десять років у НІАЗ «Ольвія» було створено нову та суттєво замінено стару експозицію в Лапідарії. Ця робота проводиться за постійної участі в якості консультанта на громадських засадах старшого наукового співробітника археологічних фондів Національного музею історії України М.А. Хомчик. Наразі відділ проводить доукомплектування експозиції у закритому приміщенні, її розділено на окремі частини за функціональним використанням виробів з каменю. Також продовжується робота по відокремленню (поки що не проведена документально) та створенню допоміжного фонду, ставиться на облік експозиційні предмети у музеї та на майданчиках просто неба, проводиться постійна реставрація експонатів. Лапідарій повністю залучено в оновлений туристичний маршрут НІАЗ. Для кожного археологічного музею лапідарій є невід'ємною частиною експозиції, особливо для античного міста. Експозиційну частину лапідарію впорядковано відповідно до функціонального використання кам'яних виробів та архітектурних деталей ${ }^{19}$.

Станом на сьогодні фондосховище у НІАЗ «Ольвія» - чи не найбільше серед тих, в яких зберігаються матеріали з розкопок Ольвії, її некрополя та поселень хори. У 2015 р. фонди НІАЗ «Ольвія» постановою Вченої ради ІА НАНУ отримали науковий статус як місце зберігання масових археологічних колекцій, що походять з наукових розкопок пам'яток Ольвійського полісу. Археологічні фонди разом з музеєм $є$ окремим підрозділом НІАЗ «Ольвія». Діяльність співробітників фондів спрямована на збереження, систематизацію, каталогізацію та дослідження окремих груп археологічних матеріалів, постійний моніторинг їх стану. Низка цих робіт проводиться у співдружності з науковцями Ольвійської археологічної експедиції IA НАНУ.

Матеріали археологічних колекцій, що зберігаються у фондах, є частиною Музейного фонду та Національного надбання України. Серед найближчих завдань - розширення фондів та облаштування нового сховища відкритого типу для зберігання колекції античних амфор VI ст. до н.е. - IV ст. н.е., яка налічує близько двохсот тільки цілих форм. Таке сховище, за прикладом аналогічних зібрань на багатьох середземноморських і причорноморських пам'ятках, слугуватиме як навчальним посібником при проходженні студентами вишів археологічної практики, так і частиною експо-

18 Шевченко Т.М. Музей в НІАЗ «Ольвія» НАН України // Північне Причорномор'я за античної доби. Київ, 2017. С. 270-271.

${ }_{19}$ Хомчик М.А., Каганюк В.А. Кам'яні ядра для метательних машин з Ольвї̈// Археологія. 2017. Вип. 2. С. 54. 
зиції для спеціалізованих екскурсій. Такі першочергові заходи по упорядкуванню Наукових фондів дозволять повноцінно залучити НІАЗ «Ольвію» для туристичної скарбниці України.

\section{REFERENCES}

Buiskikh, A.V. \& Chepkasova, M.I. (2010). Kollektsiia vostochnogrecheskoi i korinfskoi keramiki iz Olvii v sobranii Nikolaevskogo oblasnogo kraevedcheskogo muzeia obshchaia kharakteristika [A collection of East Greek and Corinthian ceramics from Olbia in the collection of the Nikolaev Regional Museum of Local Lore (general description)]. In Istoriia. Etnohrafiia. Kultura. Novi doslidzhennia. VIII Mykolaivska kraieznavcha konferentsiia (pp. 81-82). Mykolaiv [in Russian].

Burdo, N.B. \& Son, N.O. (2007). Vstup [Introduction]. In Kataloh «Kolektsii Naukovykh fondiv IA NANU» (pp. 5-10). Kyiv: Akademperiodyka [in Ukrainian].

Zhuravlev, D.V. \& Lomtadze, G.A. (2001). Keramicheskie kompleksy iz nekropolia Olvii ellinisticheskogo vremeni [Ceramic complexes from the necropolis of Olbia of Hellenistic time]. Arkheolohiia, 1, 78-91 [in Russian].

Tolochko, P.P. (ed.). (2015). Instytut arkheolohii Natsionalnoi akademii nauk Ukrainy. 1918-2014 [Institute of Archeology of the National Academy of Sciences of Ukraine. 1918-2014]. Kyiv [in Ukrainian].

Karasev, A.N. (1976). B.V. Farmakovskii i Olviia [B.V. Farmakovsky and Olbia]. In Khudozhestvennaia kultura i arkheologiia antichnogo mira (pp. 13-21). Leningrad: Nauka [in Russian].

Kostenko, A.V. (2015). Arkheolohichni fondy kraieznavchoho muzeiu: formuvannia, zberihannia, vykorystannia (na prykladi Khersonskoho oblasnoho kraieznavchoho muzeiu). [Archaeological foundations of the Museum of Local History: formation, storage, use (on the example of the Kherson Regional Museum of Local History)]. (Candidate's thesis). Kyiv [in Ukrainian].

Krapivina, V.V. (2001). Olviia: problemy okhorony ta arkheolohichni doslidzhennia [Olbia: conservation issues and archaeological studies]. Arkheolohiia, 4, 4-8 [in Ukrainian].

Papanova, V.A. (2006). Urochishche Sto mogil nekropol Olvii Pontiiskoi [The tract One Hundred Graves (necropolis of Olbia Pontic)]. Kyiv: Znannia Ukrainy [in Russian].

Slavin, L.M. (1960). Osnovnye etapy izucheniia Olvii [The main stages of the study of Olbia]. In Zapiski Odesskogo arkheologicheskogo obshchestva, 1, 47-59. [in Russian].

Slavin, L.M. (1947). Stan Olviiskoho zapovidnyka Akademii nauk URSR [State of Olvia Reserve of the Academy of Sciences of the USSR]. Arkheolohiia, 1, 192-194 [in Ukrainian].

Tunkina, I.V. (1989). K istorii izucheniia Olvii v kontse XVIII nachale XIX v. [On the history of the study of Olbia in the late XVIII - early XIX centuries]. In Drevnee Prichernomore. Chteniia pamiati professora P.O. Karyshkovskogo. Tezisy dokladov konferentsii (pp. 52-54). Odessa [in Russian].

Tunkina, I.V. (2001). K istorii izucheniia Olvii v pervoi treti XX v. [On the history of the study of Olbia in the first third of the twentieth century]. Arkheolohiia, 4, 35-50 [in Russian].

Tunkina, I.V. (2002). Russkaia nauka o klassicheskikh drevnostiakh Yuga Rossii (XVIII - seredina XIX v.) [Russian science of classical antiquities of the South of Russia (XVIII - middle XIX century)]. SanktPeterburg: Nauka [in Russian].

Farmakovskaia, T.I. (1988). Boris Vladimirovich Farmakovskii [Boris Vladimirovich Farmakovskyy]. Kiev: Naukova dumka [in Russian].

Khomchyk, M.A. \& Kahaniuk, V.A. (2017). Kamiani yadra dlia metatelnykh mashyn z Olvii [Stone cores for throwing machines from Olbia]. Arkheolohiia, 2, 54-56 [in Ukrainian].

Shevchenko, T.M. (2017). Muzei v NIAZ «Olviia» NAN Ukrainy [Museum at the Olvia National Research Institute of NAS of Ukraine]. In Northern Black Sea coast in ancient times. Kyiv [in Ukrainian].

\section{Tetiana Shevchenko}

(Olbia National Historical and Archaeological Reserve of the National Academy of Sciences of Ukraine, Parutyne, Mykolayiv region, Ukraine)

ORCID: https://orcid.org/0000-0002-4237-8074

\section{On the State of Museum and Reserve Collection Work in the National Historical and Archeological Reserve «Olbia»}

The paper is devoted to a brief overview of the history of the archaeological collection forming, which is stored in the Scientific Reserve Collections and the Museum of the National 
Historical and Archeological Reserve «Olbia» (NIAZ) of the National Academy of Sciences of Ukraine. The main reasons for the creation of a storage facility and a museum at the excavations site are analyzed. The formation of the own repository in the reserve «Olbia» began in 1935 . From the very beginning, the repository has been forming on the principle of forming the complex archaeological collections with mass archaeological material. Most probably, the museum was established in Olbia at the same time with the reserve collections depository, approximately in 1941. Even though a large part of the archaeological collections of the 30s-70s is stored in the reserve repository, there were no clear requirements for their conveying by the relevant deeds, and the status of the reserve collections as the repository of the archaeological collections containing mass materials was not determined. At present, only the inventories describing archaeological findings have remained of the old collection documentation.

Starting from 1981, almost all archaeological materials found during the excavations of the Olbian Archeological Expedition of the Institute of Archaeology of the National Academy of Sciences of Ukraine (IA NASU) are conveyed for permanent conservation to the NIAZ «Olbia» by the deeds of conveyance and with the corresponding collection descriptions.

As of today, the archaeological collection of the reserve includes 131474 specimens of storage, 465 of which are on a permanent exhibition of the Museum of Ceramics, about 1000 specimens are exhibited in the lapidarium, another 68 specimens were conveyed for permanent exhibition to the Mykolaiv Regional Museum of Local Lore «Staroflotski Barracks» with which NIAZ maintains a long-standing and close relations. Thanks to the excavations of the Olbian Archeological Expedition of the IA NASU, the Scientific Reserve Collections of the NIAZ «Olbia» are annually broadened with new findings, just as mass so presentable or exhibitional.

Due to the lack of necessary storage conditions and, premises, that would meet the modern conditions of archaeological materials storage in general, the NIAZ «Olbia» Scientific Reserve Collections, as well as the Museum of Ceramics, still cannot provide the necessary temperature and humidity regime, and certain findings such as numismatic materials, as well as certain categories of metal productions, are taken out and conveyed by the corresponding deeds for permanent storage to the Scientific Reserve Collections of the IA NASU.

The extremely limited exhibition area of the NIAZ «Olbia» Museum of Ceramics does not allow creating such an exposition, which would fully characterize all aspects of the life of ancient Olbia during the thousand-year period of its existence. Therefore, the current exposition of the Museum of Ceramics in the NIAZ presents only certain thematic areas, such as the earliest imports to Olbia, the main types of incoming utensils of pre-Roman and Roman times, the findings from the necropolis, the utility nook with the main types of moulded utensils, pottery and the main kinds of local and general handicraft production.

Temporary exhibitions are periodically held in the round hall of the museum to demonstrate at least a small part of new specimens.

Over the last ten years, in the NIAZ «Olbia» a new exposition has been created and the old exposition has been essentially changed in the lapidarium.

The materials of the archaeological collections stored in the repository are the part of the Museum Reserve Collection and the National Heritage of Ukraine. And the activity of the employees of the repository is aimed at preservation, systematization, cataloging, and studying of certain groups of archaeological materials, and constant monitoring of their state.

Keywords: NIAZ «Olbia», reserve collections, museum, ancient archeology, national heritage, monitoring 